Check for updates

Deakin Health Economics, Deakin University, 221 Burwood Highway, Burwood, VIC 3125, Australia

2 Menzies Institute for Medical Research, University of Tasmania

Correspondence to:

martin.hensher@deakin.edu.au

Cite this as: BMJ 2020;371:m3687 http://dx.doi.org/10.1136/bmj.m3687

Published: 8 October 2020

\section{Covid-19, unemployment, and health: time for deeper solutions?}

As covid-19 drives unemployment rates around the world to levels unseen in generations, once radical economic policy proposals are rapidly gaining a hearing. Martin Hensher examines how job guarantee or universal basic income schemes might support better health and better economics

\section{Martin Hensher associate professor of health systems financing and organisation ${ }^{1,2}$}

Covid-19 has been a dramatic global health and economic shock. As SARS-CoV-2 spread across nations, economic activity plummeted, first as individuals changed their behaviour and then as government "lockdowns" took effect. ${ }^{1}$

Macroeconomic forecasters foresee a major recession continuing through 2020 and into 2021. ${ }^{2}$ Although the governments of many nations have taken novel steps to protect workers, unemployment has risen dramatically in many countries (box 1, fig 1); poverty and hunger are on the rise in low and middle income countries. ${ }^{5}$ Covid-19 has directly caused illness and death at a large scale, and further threatens health through disruption of access to health services for other conditions.

\section{Box 1: Covid-19 and unemployment}

Although unemployment soared in response to covid-19 in some nations, the policy measures undertaken by others have prevented many workers from becoming technically unemployed. In the United Kingdom, the headline rate of unemployment for April-June 2020 was $3.9 \%-$ only slightly higher than the $3.89 \%$ rate in in the coronavirus job retention scheme ("furlough") and another 2.7 million had claimed a self-employment income support scheme grant; there had been the largest ever decrease in weekly hours worked; 650 ooo fewer workers were reported on payrolls in June than in March; and the benefit claimant count had more than doubled from 1.24 million to 2.63 million people. ${ }^{3}$ The Australian Bureau of Statistics has produced an adjusted estimate of Australian unemployment that includes all those temporarily stood down or laid off, to allow a closer comparison with US and Canadian statistics (fig 1). As emergency support measures are wound back, concern is growing that the downwards trend from the April peak might not be maintained in coming months. April-June 2019. Yet in June 20209.3 million people were

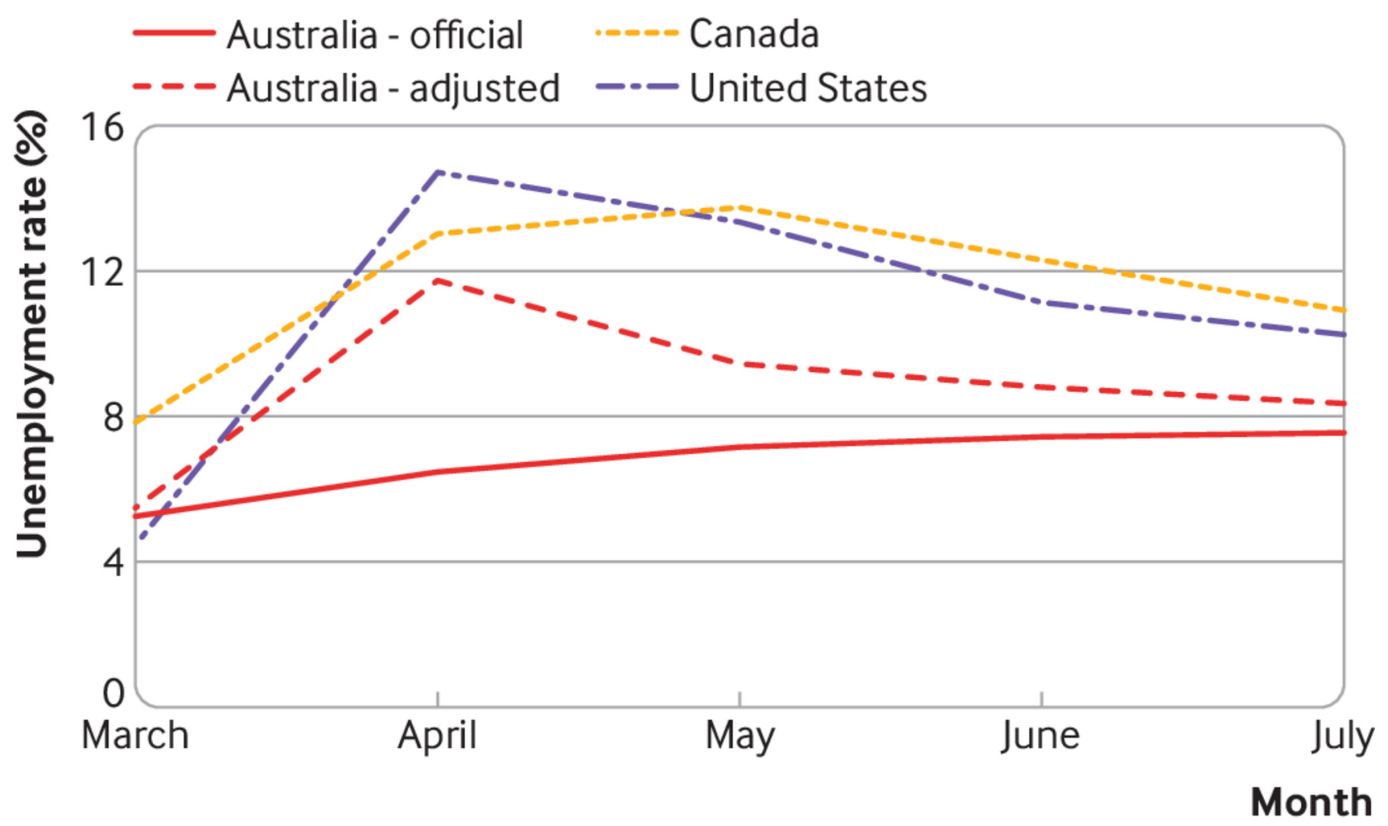

Fig 1 | Unemployment rates in Australia, Canada, and the United States from March to July $2020 .^{4}$

The pandemic continues to spread, and hopes for a rapid "return to normal" look increasingly unfounded. The economic consequences of covid-19 have the potential to further damage human health if not managed effectively-even after the pandemic has faded. Even with the most rose tinted views of recovery, the effects of covid-19 on unemployment are likely to be substantial and long lived. Ambitious responses to the imminent scourge of mass unemployment are being discussed. Two such proposals $-\mathrm{a}$ job guarantee and universal basic income-might protect and promote health as well as prosperity. Governments around the world should consider radical plans to safeguard their citizens' livelihoods and wellbeing. 


\section{Unemployment and health in the time of covid-19}

Decades of accumulated evidence show a strong and consistent association between unemployment and a range of adverse health outcomes, including all cause mortality, death from cardiovascular disease and suicide, and higher rates of mental distress, substance abuse, depression, and anxiety. ${ }^{6-8}$ Job insecurity is similarly associated with poorer self-assessed health status, mental distress, depression, and anxiety. ${ }^{9}$ Unemployment and economic adversity are intimately related with despair and lack of hope, which have increasingly been linked with mortality and the rise and severity of the US opioid epidemic. ${ }^{10} 11$ Whether recessions and mass unemployment increase aggregate mortality is less clear; historical studies indicated improvements in mortality during the Great Depression in the $19305,{ }^{7}$ but more recent US research found that older workers (aged 45-66) who lose their jobs in a recession have higher mortality than those who lose their jobs in boom times. ${ }^{12}$

Insecurity, precariousness, and austerity harmed both unemployed and employed people during the protracted economic crisis in Greece after 2008-09. ${ }^{13}$ Meanwhile, differing welfare state institutions and unemployment insurance arrangements directly limit or amplify health inequalities in a society. ${ }^{714}$

These factors could adversely affect the health of growing numbers of unemployed workers after covid-19. ${ }^{15}$ Governments, business lobbyists, and civil society advocates around the world are debating how economies might best recover from the covid recession. Although governments currently acknowledge the need to spend freely during the crisis, experience suggests that pressure to pursue misguided austerity policies might grow, threatening subsequent recovery. Options on the table range from "green new deal" programmes to build a post-carbon economy and national industrial strategies to bring globalised manufacturing back onshore through to calls for reducing wages and labour protections to "free up" labour markets. Yet these are all indirect approaches to the effects of unemployment. Proposals for a job guarantee or a universal basic income seek to act more directly to support individual citizens.

\section{The job guarantee}

The idea of a right to employment can be traced back to the US New Deal in the 1930s, and to Article 23 of the 1948 United Nations Universal Declaration of Human Rights. More recently, in the contest for the Democratic Party's 2020 candidate for US president, senators Bernie Sanders, Kirsten Gillibrand, and Cory Booker all included a job guarantee in their platforms, as did Alexandria Ocasio-Cortez's green new deal resolution. More than one detailed proposal for a Federal Job Guarantee has been published in the US ${ }^{17} 18$ and in Australia. ${ }^{19}$ In one US proposal, ${ }^{18}$ a federally funded public service employment programme would provide a standing offer of work at a living wage $(\$ 15$ (£12; $€ 13)$ an hour), along with key benefits including healthcare coverage. Employees of this programme would be deployed on a wide range of public works and community development activities, delivered through federal, state, local, and non-profit agencies. The proposal argues that this would effectively eliminate unwanted joblessness and underemployment and would rapidly force the private sector to increase wages to match this "living wage" alternative, lifting millions out of poverty and greatly improving the incomes of working poor people. ${ }^{18}$ Proponents argue that the job guarantee is the most efficient "automatic stabiliser" for the economy throughout the business cycle, able to adjust up and down to reflect the changing economic health of the private sector. In economic downturns, it would provide guaranteed employment to stop people falling into poverty and losing “employability,” while also supporting aggregate demand to lift the economy out of recession. In boom times, workers will simply exit the programme for the private sector, as firms offer higher wages to secure the additional labour they need.

In the US, the job guarantee has been proposed as not only a key tool for recovery from covid $-19,{ }^{20}$ but also a mechanism to ensure that this recovery breaks down historically entrenched racial inequalities in wealth. ${ }^{21}$ Similarly, an emerging job guarantee proposal for Australia could rectify decades of welfare policy failures that have disproportionately affected indigenous Australians. ${ }^{22}$ Proponents point to successful past or present international experiences with full or targeted employment guarantee programmes, including Argentina's Plan Jefes, South Africa's Expanded Public Works Programme, India's National Rural Employment Guarantee Act, Belgium's Youth Job Guarantee, the US Youth Incentive Entitlement Pilot Projects, and the UK's Future Jobs Fund. ${ }^{20}$

\section{Universal basic income}

Over the past few years, there has been a global explosion of interest in the concept of universal basic income. ${ }^{23-25}$ Andrew Yang, another former contender for the 2020 Democrat presidential nomination, made universal basic income a central plank of his platform. Such proposals share key characteristics: they are a transfer of income (from the state to individuals) that is provided universally (to everyone, with no targeting), unconditionally (with no requirements, for example to work), and in cash (with no controls on what the money can be spent on). ${ }^{25}$ Proposals also typically specify an income that is sufficiently generous that it can fully cover a basic level of living expenses. ${ }^{23}$ Universal basic income is a direct means of reducing poverty, by ensuring that all in society receive enough to live with dignity; it could reduce income inequality; it could radically simplify current social welfare systems and remove poverty traps and disincentives to move from welfare into work; it could improve the ability of workers to refuse poorly paid, insecure, exploitative or unsafe jobs, through a reduced fear of loss of income; and it could be a buffer against technological unemployment, as automation and artificial intelligence replace human labour. ${ }^{23} 25$ Universality is the key difference from today's welfare systems; everyone should receive universal basic income as a right of citizenship, and its receipt by all should build the solidarity and legitimacy that will sustain this right. Universal basic income could improve health and reduce health inequities through direct action on various social determinants of health. ${ }^{26} 27$ This variety of aims leads to the concept being simultaneously supported by those on the left as a radical, anti-capitalist policy, often viewed as an essential component of the ecological degrowth agenda, and by libertarian, tech capitalists as an efficient solution to the risk that ever expanding digital automation will destroy more jobs than it creates, and as a vital measure to help capitalism survive mass technological unemployment in the future. ${ }^{28}$

In the wake of the covid-19 economic shock, universal basic income has been discussed as a potentially powerful policy solution to unprecedented economic dislocation. It has specifically been suggested as a tool for limiting the economic, social, and psychological trauma of covid-19. ${ }^{29}$ The Spanish government has just introduced a nationwide, means tested minimum income programme (not universal) as a direct response to covid related unemployment. ${ }^{30}$ The US government has made unconditional, one-off economic impact payments to most (but not all) American households. Near universal and unconditional universal basic income programmes have only operated at nationwide scale in two countries, Mongolia and Iran. The Mongolian programme has since ceased, and the Iranian programme is no longer strictly universal 
(the richest people are no longer eligible). Partial schemes and regional pilots, however, have been run successfully in a wide range of nations. ${ }^{25}$ A recent trial that provided universal basic income to 2000 recipients in Finland found that employment outcomes, health, and wellbeing measures were better in the universal basic income group than in the comparison group, ${ }^{31}$ and the Scottish government has been contemplating a three year trial of universal basic income in an experimental group of recipients. ${ }^{32}$

\section{Potential health benefits}

Given the substantial evidence linking unemployment to poor health, proponents of both job guarantee and universal basic income schemes point to their potential health benefits as major arguments in their favour (table 1). ${ }^{20}{ }^{26}$ These measures could be expected to positively affect health through four main pathways: direct effects for individual beneficiaries; knock-on effects improving labour market conditions for all workers; the macroeconomic and distributive benefits of more widespread prosperity; and more localised community effects unlocked by these programmes.

Table 1 | Health effects of job guarantee (JG) and universal basic income (UBI) programmes

\begin{tabular}{|c|c|c|c|}
\hline Mechanisms & $J G$ & UBI & Potential health benefits \\
\hline \multicolumn{4}{|l|}{ Direct benefits for individuals } \\
\hline $\begin{array}{l}\text { Decreased unemployment and } \\
\text { underemployment }\end{array}$ & Yes & Maybe & \multirow{9}{*}{$\begin{array}{l}\text { Reduced premature mortality from suicide, } \\
\text { substance abuse, cardiovascular disease, all } \\
\text { cause mortality } 6.812 \\
\text { - Reduced mental distress, depression, and } \\
\text { anxiety } 89 \\
\text { Reduced opioid and other substance } \\
\text { abuse } 1033 \\
\text { - Better access to healthcare } 34 \\
\text { Short term disability less likely to progress to } \\
\text { - Iong term disability } 35\end{array}$} \\
\hline Reduced incentive to claim disability benefits & Yes & Maybe & \\
\hline Living wage & Yes & No & \\
\hline Decreased household poverty & Yes & Yes & \\
\hline Reduced job insecurity & Yes & Yes & \\
\hline Reduced pressure to take "bad" jobs & Yes & Yes & \\
\hline Healthcare coverage (US) & Yes & No & \\
\hline Better able to balance part or full time work & Yes & Yes & \\
\hline $\begin{array}{l}\text { Better able to prioritise caring or non-market } \\
\text { activities }\end{array}$ & No & Yes & \\
\hline \multicolumn{4}{|l|}{ Impacts on wider labour market } \\
\hline Increased wages for all low paid workers & Yes & No & \multirow[t]{5}{*}{ As above } \\
\hline Reduced job insecurity & Yes & Yes & \\
\hline $\begin{array}{l}\text { Increased pressure for all employers to provide } \\
\text { benefits (eg, paid sick leave, health coverage) }\end{array}$ & Yes & Maybe & \\
\hline $\begin{array}{l}\text { Eliminates welfare traps and disincentives to } \\
\text { take jobs }\end{array}$ & Yes & Yes & \\
\hline $\begin{array}{l}\text { New entrepreneurs can create business and } \\
\text { jobs }\end{array}$ & No & Yes & \\
\hline \multicolumn{4}{|c|}{ Macroeconomic multiplier effects on aggregate demand } \\
\hline $\begin{array}{l}\text { Increased disposable incomes and } \\
\text { consumption lead to decreased unemployment }\end{array}$ & Yes & Yes & As above \\
\hline \multicolumn{4}{|l|}{ Community benefits } \\
\hline $\begin{array}{l}\text { Community development, cohesion, and } \\
\text { renewal }\end{array}$ & Yes & Yes & \multirow{5}{*}{$\begin{array}{l}\text { Reduced opioid and other substance abuse }{ }^{33} \\
\text { Reduced isolation and mental distress } 36 \\
\text { Improved physical activity }\end{array}$} \\
\hline $\begin{array}{l}\text { Formal support programmes for elderly, frail, } \\
\text { vulnerable people }\end{array}$ & Yes & No & \\
\hline Informal care for elderly, frail, vulnerable people & No & Yes & \\
\hline $\begin{array}{l}\text { Volunteering, community engagement, and } \\
\text { spirit }\end{array}$ & No & Yes & \\
\hline Local environmental improvements & Yes & Maybe & \\
\hline
\end{tabular}

Multiple mechanisms would work through these four pathways to deliver potential health benefits, including reduced mortality and improved physical and mental health status. Key mechanisms include reducing poverty, improving economic security, improving the quality of jobs and work, and rebuilding stronger local communities. Unsurprisingly, pathways that link unemployment with poorer health will be more reliably affected by job guarantee programmes than by universal basic income. But universal basic income offers alternative pathways for better health through informal caring and non-market activities. Both types of programme could help resolve one of the problems that the covid-19 pandemic has brought into sharp focus-that low paid, insecure, and casualised workforces cannot afford to self-isolate or stay at home when sick or potentially infected because they lack access to paid sick leave. This problem has proved especially disastrous for those who care for elderly people.

\section{Controversies and choices}

Supporters of job guarantee or universal basic income programmes typically have different priorities and view them as two alternative options, not as complementary programmes that could co-exist. Most job guarantee proposals see it as not only a means to fight unemployment, but also an explicit instrument of macroeconomic policy $^{38}$; universal basic income would not function as an 
"automatic stabiliser" in the same way. Critics of job guarantee and universal basic income schemes primarily question their affordability and potential macroeconomic consequences (box 2).

\section{Box 2: Economic controversies}

Implementing a job guarantee or universal basic income programme would be a major economic reform in any nation and a decisive break with the economic orthodoxy that has prevailed since the Thatcher-Reagan revolution of the 1980 s. It would undoubtedly be controversial. Most obviously, some would question them on cost and affordability grounds. A job guarantee programme would incur a substantial net cost to governments-modelling of proposed programmes indicates a net cost to the federal budget equivalent to $1.5 \%$ of annual general domestic product (GDP) in the US ${ }^{18}$ and $2.6 \%$ in Australia (based on a net budgetary cost of $A \$ 51.7 \mathrm{bn}) .{ }^{19} \mathrm{By}$ comparison, the Australian government is spending $A \$ 70 b n$, or $3.6 \%$ of its GDP, on its emergency JobKeeper employment protection programme this year-budget costs of these magnitudes are not unheard of. The gross costs of a universal basic income programme would be substantially larger: income of $\$ 12000$ (close to the 2017 US poverty line) for every US adult would cost the federal budget about \$3tn, or nearly $14 \%$ of GDP. ${ }^{23}$ Yet this gross cost estimate is arguably misleading, 39 not only because universal basic income would be partially offset by large savings from current welfare programmes, but because so many recipients would return much or all of it in the form of tax payments. One estimate of the net cost of such a programme indicates that it could be as low as $2.95 \%$ of US GDP. 39 These proposals emerge as a growing number of economists are saying that the governments of countries in possession of their own sovereign currency can never "run out of money" and can always purchase whatever goods and services are for sale in the currency they issue. ${ }^{38}{ }^{40}$ They also suggest that inflation-the other risk often pointed to by critics of job guarantee or universal basic income-is currently highly unlikely, with a general fear that the covid-19 recession will prove to be deflationary rather than inflationary.

For those concerned with health, however, philosophical differences might be of more interest. Social determinants and socioeconomic inequalities are well understood to be powerful forces driving health outcomes at both individual and population levels. Universal basic income seeks to reduce poverty and inequality by putting in place an absolute floor-a minimum income provided to everyone in society. A job guarantee seeks to affect poverty by ensuring that anyone who wants to work can work, for a living wage in a decent job. But in so doing, a job guarantee also explicitly increases the relative power of workers, ensuring that a larger share of national income flows to labour, rather than to the owners of capital-potentially reducing some of the extreme inequalities in income and wealth distribution that have arisen over the past four decades. One criticism of universal basic income is that it might (whether inadvertently or by design) become a "plutocratic, philanthropic" programme ${ }^{28}$-scraps from the table of the ultra wealthy, which might cement dependence and powerlessness in a future of technological unemployment. Equally, a job guarantee might be criticised as being a mid 2oth century solution to a 21st century problem, which will reinforce social hierarchies by insisting on participation in paid employment as the solution to poverty.

\section{Conclusion}

The unemployment triggered by covid-19 in so many countries is a clear and present danger to individual and population health. Tinkering around the margins of current welfare systems, exhortations for yet more labour market "flexibility," or an unwillingness to maintain public spending through a potentially long and drawn out downturn all offer a fast track to poor outcomes. The scale of the covid economic shock demands more radical action.
The substantial health harms of unemployment might be mitigated by a universal basic income programme, but if unemployment is the problem, then employment seems likely to deliver more effective mitigation along the many and complex pathways by which these harms are transmitted. If so, implementing national job guarantee programmes should be a more urgent priority for governments in the immediate aftermath of covid-19. A successful job guarantee scheme would avert the harms of unemployment, strengthen the position of ordinary working people, and deliver a more broadly distributed prosperity in the short to medium term. This would be a much better position from which to then debate and trial universal basic income, allowing it to be correctly framed as a strategic, long term solution to the changing future of work, rather than simply as a response to the current economic crisis.

\section{Key messages}

- Covid-19 has triggered economic recession and unprecedented rapid rises in unemployment in many countries

- Mass unemployment has the potential to cause grave harm to individual and population health if not effectively mitigated

- The scale of the crisis means that radical solutions might need to be considered, such as a job guarantee or universal basic income programmes

- These policies have the potential to protect human health and dignity, but would mark a significant break with economic orthodoxy

Contributors and sources: $\mathrm{MH}$ has worked on health financing, planning, and economics as a senior policy maker and researcher in the UK, South Africa, and Australia and as a consultant for the World Bank, World Health Organization and the European Commission. His research on the ecological and economic sustainability of healthcare systems has included examining a number of emerging heterodox economic approaches, two of which are gaining in significance: ecological economics and modern monetary theory. Members of these schools have promoted universal basic income and a job guarantee respectively, over many years. This article builds on the existing academic literature to consider very recent policy proposals that are emerging in response to the threat of mass unemployment in the wake of covid-19.

Patient involvement: No patients were involved.

Competing interests: I have read and understood BMJ policy on declaration of interests and have the following interests to declare: this research was supported by an Australian Government Research Training Scholarship.

I acknowledge the Wurundjeri people of the Kulin Nation as the traditional owners of the land on which this work was undertaken.

Goolsbee A, Syverson C. Fear, lockdown, and diversion: comparing drivers of pandemic economic decline 2020. National Bureau of Economic Research, June 2020. https://www.nber.org/papers/w27432

2 International Monetary Fund. World economic outlook update: a crisis like no other, an uncertain recovery. June 2020. https://www.imf.org/en/Publications/WEO/Issues/2020/06/24/WEOUpdateJune 2020

3 Office for National Statistics. Labour market overview, UK: August 2020. 2020. https://www.ons.gov.uk/employmentandlabourmarket/peopleinwork/employmentandemployeetypes/bulletins/uklabourmarket/august2020

Australian Bureau Statistics. Understanding unemployment and the loss of work during the covid-19 period: an Australian and international perspective. 13 August 2020. https://www.abs.gov.au/articles/understanding-unemployment-and-loss-work-during-covid-19period-australian-and-international-perspective

World Bank. World Bank Group. 100 countries get support in response to covid-19.19 May 2020. https://www.worldbank.org/en/news/press-release/2020/05/19/world-bank-group-100-countriesget-support-in-response-to-covid-19-coronavirus

6 Jin RL, Shah CP, Svoboda TJ. The impact of unemployment on health: a review of the evidence. CMA/1995;153:529-40.pmid: 7641151

Stuckler D, Basu S. The body economic: why austerity kills. Allen Lane, 2013.

8 Paul KI, Moser K. Unemployment impairs mental health: meta-analyses. J Vocat Behav 2009; 74:264-82doi: 10.1016/j.jvb.2009.01.001

9 Kim TJ, von dem Knesebeck O. Is an insecure job better for health than having no job at all? A systematic review of studies investigating the health-related risks of both job insecurity and unemployment. BMC Public Health2015;15:985. doi: 10.1186/s12889-015-2313-1 pmid: 26419739

10 Case A, Deaton A. Mortality and morbidity in the 21st century. Brookings Institution, 2017doi: 10.1353/eca.2017.0005 
11 Graham C, Pinto S. Unequal hopes and lives in the USA: optimism, race, place, and premature mortality. J Popul Econ 2019;32:665-733doi: 10.1007/s00148-018-0687-y.

12 Noelke C, Beckfield J. Recessions, job loss, and mortality among older US adults. Am J Public Health 2014;104:e126-34. doi: 10.2105/AJPH.2014.302210. pmid: 25211731

13 Barlow P, Reeves A, McKee M, Stuckler D. Austerity, precariousness, and the health status of Greek labour market participants: Retrospective cohort analysis of employed and unemployed persons in 2008-2009 and 2010-2011. J Public Health Policy 2015;36:452-68. doi: 10.1057/jphp.2015.25. pmid: 26290470

14 Beckfield J, Bambra C, Eikemo TA, Huijts T, McNamara C, Wendt C. An institutional theory of welfare state effects on the distribution of population health. Soc Theory Health 2015;13:227-44doi: 10.1057/sth.2015.19.

15 McKee M, Stuckler D. If the world fails to protect the economy, COVID-19 will damage health not just now but also in the future. Nat Med 2020;26:640-2.

doi: 10.1038/s41591-020-0863-y. pmid: 32273610

16 Deady M, Tan L, Kugenthiran N, Collins D, Christensen H, Harvey SB. Unemployment, suicide and COVID-19: using the evidence to plan for prevention. Med J Aust (Preprint).pmid: 32729145

17 Paul M, Darity W, Hamilton D. The federal job guarantee-a policy to achieve permanent full employment. Center on Budget and Policy Priorities, 2018.

18 Wray LR, Dantas F, Fullwiler S, Tcherneva P, Kelton S. Public service employment: a path to full employment. Levy Economics Institute of Bard College, 2018.

19 Mitchell WF, Watts M. Investing in a job guarantee for Australia. Centre of Full Employment and Equity. July 2020. http://www.fullemployment.net/publications/reports/2020/CofFEE_Research_Report_2000-02.pdf

20 Tcherneva P. The case for a job guarantee. Polity Press, 2020.

21 Hamilton D, Asanthe-Muhammad D, Collins C, Ocampo O. White supremacy is the pre-existing condition: eight solutions to ensure economic recovery reduces the racial wealth divide. Insitute for Policy Studies, 2020

22 Pearson N. The case for a government jobs guarantee. The Australian. 4 July 2020. https:/www.theaustralian.com.au/commentary/the-case-for-a-government-jobs-guarantee/newsstory/dee6e9545cd5af967c853e2f0481b02d

23 Hoynes H, Rothstein J. Universal basic income in the United States and advanced countries. Annu Rev Econ 2019;11:929-58doi: 10.1146/annurev-economics-080218-030237.

24 Banerjee A, Niehaus P, Suri T. Universal basic income in the developing world. Annu Rev Econ 2019;11:959-83doi: 10.1146/annurev-economics-080218-030229.

25 Gentiline U, Grosh M, Rigolini J, Yemtsov R. Exploring universal basic income: a guide to navigating concepts, evidence and practices. The World Bank Group, 2020.

26 Ruckert A, Huynh C, Labonté R. Reducing health inequities: is universal basic income the way forward?) Public Health (Oxf) 2018;40:3-7. doi: 10.1093/pubmed/fdx006. pmid: 28158715

27 Painter A. A universal basic income: the answer to poverty, insecurity, and health inequality?BMJ 2016;355:i6473. doi: 10.1136/bmj.i6473. pmid: 27956433

28 Fouksman E, Klein E. Radical transformation or technological intervention? Two paths for universal basic income. World Dev 2019;122:492-500doi: 10.1016/j.worlddev.2019.06.013.

29 Johnson MT, Johnson EA, Webber L, Nettle D. Mitigating social and economic sources of trauma: The need for universal basic income during the coronavirus pandemic. Psychol Trauma 2020:12(S1):S191-2. doi: 10.1037/tra0000739. pmid: 32551770

30 Dombey D, Sandbu M. Spain to push through minimum income guarantee to fight poverty. Financial Times, London. 28 May 2020. https://www.ft.com/content/0b6a5d25-e078-4dfc-b314f659b566317e

31 Kangas O, Jauhiainen S, Simanainen M, Ylikännö M. Evaluation of the Finnish Basic Income Experiment/Suomen perustulokokeilun arviointi Helsinki: Ministry of Social Affairs and Health/Sosiaali- ja terveysministeriö; 2020. https://julkaisut.valtioneuvosto.fi/bitstream/handle/10024/162219/STM_2020_15_rap.pdf

32 Paton C. Coronavirus in Scotland: Nicola Sturgeon eyes plans for universal basic income. The Times, London. 5 May 2020. https://www.thetimes.co.uk/article/nicola-sturgeon-eyes-plans-foruniversal-basic-income-c9rhfwbx7

33 Nagelhout GE, Hummel K, de Goeij MCM, de Vries H, Kaner E, Lemmens P. How economic recessions and unemployment affect illegal drug use: A systematic realist literature review. Int J Drug Policy 2017;44:69-83. doi: 10.1016/j.drugpo.2017.03.013. pmid: 28454010

34 Hasdell R. What we know about universal basic income: a cross-synthesis of reviews. Stanford Basic Income Lab, 2020.

35 O’Day B, Kleinman R, Fischer B, Morris E, Blyler C. Preventing unemployment and disability benefit receipt among people with mental illness: evidence review and policy significance. Psychiatr Rehabil / 2017;40:123-52. doi: 10.1037/prj0000253. pmid: 28368137

36 Gardiner C, Geldenhuys G, Gott M. Interventions to reduce social isolation and loneliness among older people: an integrative review. Health Soc Care Community 2018;26:147-57. doi: 10.1111/hsc.12367. pmid: 27413007

37 Olanrewaju O, Kelly S, Cowan A, Brayne C, Lafortune L. Physical activity in community dwelling older people: a systematic review of reviews of interventions and context. PLoS One 2016;11:e0168614. doi: 10.1371/journal.pone.0168614. pmid: 27997604

38 Mitchell W, Wray LR, Watts M. Macroeconomics. Macmillan International / Red Globe Press, 2019.

39 Widerquist K. The cost of basic income: back-of-the-envelope calculations. Basic Income Studies 2017;12:107-18doi: 10.1515/bis-2017-0016
40 Skidelsky R. Money and government: a challenge to mainstream economics. Penguin Books, 2019. 